\title{
Slavery and Identity in Mozarabic Toledo: 1201-1320
}

\author{
Michael A. Ryan
}

Resum. Esclavitud $i$ identitat en el Toledo mossarab: 1201-1320

L'ocupació musulmana de Toledo va significar la coexistència, en aquesta ciutat, de col-lectius que professaven religions diferents i entre els quals la tensió era freqüent: mossàrabs, jueus, castellans i colons francesos es convertiren en els grups dominants de la ciutat. Els musulmans de Toledo van haber d'escolllir entre fugir, batejar-se o acabar com a captius o esclaus dels conqueridors.

Spain has always occupied a unique place in the West. It is through its geography that Spain's culture and history are, in many ways, defined. The westernmost point of the Eurasian landmass, the Iberian peninsula has an area of roughly 581,000 square kilometers ${ }^{1}$. The interior of the peninsula, dry and extensive, is a central meseta, about 600 meters above sea level, and constitutes almost half of the peninsular area ${ }^{2}$. Because of its arid climate and mountainous terrain, separating the interior of the peninsula from its coast, Iberian population centers were focused on the peninsula's five great river basins: the Ebro, the Duero, the Tagus, the Guadiana, and the Guadalquivir.

Iberia itself was populated as far back into the Paleolithic period, and those people shad been overlaid in part and in turn by Phoenician, by Carthaginian, by Greek, and by Cels ${ }^{3}$. Although civilization, and substantial development, was brought by these peoples, true unity was not achieved until Rome appeared upon the scene. Beginning with the Second Punic War, from 218-201 $\mathrm{BC}$, Rome had gradually established its control over the Iberian populace. For Rome, Hispania was the westernmost point of its empire. As such, Rome considered Hispania merely as "a collection of Roman provinces politically" ${ }^{4}$, far from the center of activity of the Mediterranean world.

1. ReILLY, Bernard F. The Medieval Spains, p. 1.

2. ReIIIY, p. 1.

3. REILIY, p. 1.

4. REILIY, p. 1. 
Still, Rome left her mark, both physically and culturally, upon Iberia. Roman roads and aqueducts stretched across the countryside, linking the disparate human communities of Hispania. Rome also changed the character of the villages it conquered, turning them into cities. Though they burgeoned in population and area, they were still provincial and not considered as important as the larger and older urban centers of the empire. Those Iberian cities were targely political and administrative devices ... [they] seldom had any important industry and often not even a commerce beyond that of victualizing the government and its garrisons $n^{5}$.

Roman Iberia became thoroughly Romanized early in its existence, Spain adopted the law, the language, the culture, and eventually the religion of classical Rome. Moreover, Hispania produced some truly stellar figures in the arena of Latin scholarship, including Seneca, Lucian, Quintilian, Columella, and Prudentius. The achievements of these urban scholars and statesmen illustrate an important fact: although the ediffusion of this culture was limited to very narrow circles and ... hardly extended beyond the towns ${ }^{6}$, the genesis of such achievements from a frontier area of the Roman world demonstrates the great extent to which Hispania had developed since it came under Roman political rule.

The towns themselves, the centers of Roman culture and energy, were to play an important role. The largest cities, such as Gades, Toletum, Caesaraugusta, Emerita Augusta, and others, would become the foci of both the medieval and the Spanish worlds. Although the majority of the populace of Iberia was agrarian, the cities were centers where the members of society's various strata existed in close proximity of one another. Slave and senator, soldier and artisan, day laborer and beggar, all were crowed into the Roman cities. And these cities would grow larger, as enfranchised slaves, dispossessed farmers, and travellers from all walks of life streamed in from the countryside. Although Roman in character, the cities developed their own jentities. As time passed and as the population grew, the cities became more «Spanish" in both name and in nature. Cádiz, Toledo, Zaragoza, Mérida, and the rest, were now Spanish in name, yet bore the imprints of their Roman past. As mentioned above, these cities were centered around Iberia's five river basins, due to the aridity of the peninsula's climate. One of those basins, the Tagus, was one of Iberia's most substantial rivers, stretching for more than 1,100 kilometers and comprising about 81,000 square kilometers? An impressive river, the Tagus, lying south of the Sierra de Guadarrama mountains, flows westward across almost three-quarters of the peninsula, finally pouring into the Atlantic Ocean at journey's end. Due to its enormous size, and its navigable waterways, literally hundreds of towns and cities sprang up along its banks. Toledo, the Roman Toletum, was one of those

5. RFILY, p. 5-6.

6. Bonnassie, Pierre. From Slavery to Feudalism in South-Western Europe, p. 64.

7. REIL,Y, p. 2. 
cities, and the river embraced the city tightly against its western, southern, and eastern walls.

The Romans, in fear for their crumbling empire, gradually withdrew legions from Hispania during the first few centuries A.D. After the complete withdrawal of Roman forces, Spain was invaded by various barbarian tribes. Vandals, Alans, and Suevi entered the peninsula via the Pyrenees Mountains, and scattered themselves across the land. The Visigothic entry into Iberia, occurring in the later fifth century, would be a far stronger influence on Spanish history than that of other tribes. The Visigothic conquest of Iberia resulted in the quasi-political unity of Spain, vaguely reminiscent of the unity present during the period of Roman rule. They did embrace one legacy of the Roman past: their particular style of state religion, their Christianity. As Reilly writes, the Christianity that the Visigoths had accepted as their own "would furnish an alternative, a counter-identity to an Iberian population submerged benearh the tide of Islam. As Mozarabic Christians they would endure» ${ }^{8}$.

Toledo was a melting pot of culture for Spain in the medieval era. Church steeple and mosque's minaret alike were reflected in the waters of the Tagus. The murmurings of the Christian faithful combined with the songs of the Jewish cantors and the calls of the muezzin. The bustle of the mercado and the plaza, where merchants hawked their wares and beggars pleaded for alms, added to the life and the vibrancy of the city. Because of this eclectic mix of people and cultures, Toledo proved to be integral to the life, culture, and history of Spain, from its days as the Visigothic capital of the councry, to its time as a Muslim taifa kingdom, to its subsequent reconquest by the Christians. During its cenruries of development, Toledo thrived on this identity as a center of various ethnic groups and their achievements. This is not to say that Toledo alone exhibited this blending of cultures. Many of the cities of Spain and Portugal, especially those of the southern part of the peninsula, had the same characteristics as Toledo. However Toledo, because of its longstanding ties to the Roman Christian Church, the ecclesiastical councils of its early history, and its status as the capital of the powerful Christian Visigothic kingdom, was given a status that was almost as revered as Santiago de Compostela. For one segment of its populace, the Christians, Toledo's early history was seen as especially glorious, a tradition to be kept alive throughout the ages.

The legacy of Arab culture and rule continued well after Toledo's Christian recapture. However, prior to the establishment of it as a center for Islamic identity and culture, Toledo had been part of a staunch Christian legacy. Muslim rule began to be a possibility when Rodrigo, the last Visigothic king, and his army were routed by Tarik and his combined army of North African and Nubian soldiers. For one week, beginning on July 19, 711, the battle of Becca raged on the banks of the Wadi, with Tarik emerging victorious. His victory over the Visigothic king, although a distressing event for many a 
Christian of the southern towns, was not feared by everyone; «both malcontents and Jews joyfully received him [Tarik] and threw wide open the gates of Toledo to his advances?

Jews in Toledo, prior to Tarik's arrival, were suffering especially devastating hardships, due to the earlier Visigothic kings' actions. Toledan wealth and prosperity, moreover, came from the Hebrew colony, and as Hannah Lynch points out, athe anti-Semitic movement [under the Visigoths] ... had probably no other object than the barbarians' desire to appropriate Jewish gold ${ }^{10}$. It began in 616, during the reign of Sisibuth. Although, according to Lynch's description, oservitude and blood-shedding were equally abhorrent to him ${ }^{11}$, Sisibuth had waged war with the Byzantine army on two separate occasions. Moreover, Cesari, the Byzantine emperor, procured a treaty of peace with Sisibuth only on the condition that the Jews were to be expelled from Spain. Sisibuth later published an edict demanding that the Jews accept baptism and embrace the Christian faith, within one year's time, lest they be punished. Such punishments included flogging, public ridicule, the loss of all their possessions, and ultimately, expulsion from the kingdom ${ }^{12}$. Thousands of these unfortunates suffered under the draconian laws of Sisibuth and his successors. They undoubtedly saw Tarik and his army as a welcome force, not as likely to inflict the harsh laws of Sisibuth upon their people.

The Mozarabs were those Christian minorities in medieval Spain who lived in the towns and cities that fell under Muslim domination. After the Muslim conquest of the majority of the peninsula, beginning in 711, the Mozarabs kept alive the Visigothic era in their religious rites and in their use of a Latin idiom, later called Romance Spanish, as they adapted to a new era of Muslim laws and restrictions. The Muslims treated the Mozarabs fairly liberally, as Jean Descola notes: "Christians could live on good terms with Moslems [sic] provided they observed these restrictions [on Catholicism], paid their taxes, and made no ostentatious display of their religion ${ }^{13}$. For example, church bells were not permitted to ring aloud in Toledo after the city fell to the Muslims. Over time, the Mozarabs assimilated themselves into their Muslim conqueror's culture. According to Bernard Reilly, "they gradually adopted the dress, some of the diet of the Muslims, and even achieved some degree of bi-lingualism in Arabio, ${ }^{14}$. The Toledan Mozarabs found themselves, like their city, caught between two cultures, two different ways of life.

When the Christian king Alfonso VI reconquered Toledo from the Muslims on the twenty-sixth of May, 1085, the Mozarabs found themselves in a different status. Now they were the politically dominant ethnic group, due to their

9. LrNCH, Hannah. Toledo: The Story of an Old Spanish Capital, p. 62.

10. LYNCH, p. 33.

11. LYNCH, p. 33.

12. LrNCH, p. 34.

13. Descoli, Jean. A History of Spain, p. 123.

14. REILIY, p. 60. 
newly-bestowed rights of jurisdiction and sovereignty. The remaining Muslims, those who had not fled, been killed, or converted, were in the minority. Both Muslim and Mozarab now had to contend with their respective shifts in status and the resulting identity crises that accompanied them.

Hand-in-hand with this social crisis arose the question of slavery. Slavery, although an unfortunate consequence for many a Christian and Muslim caught in the middle of the fighting between these two religious groups vying for control of the peninsula, was ever-present in Iberian society. And the Mozarabs, the link berween the Christians and Muslims, owned a number of Muslim slaves. The fact that both Mozarabs and Jews owned Muslim slaves was abhorrent to the remaining Muslims of Toledo. What they disliked was not that the nefarious institution itself was practiced - for Muslims had previously held Christians as slaves - nor that there were Muslims who were themselves enslaved. What free Muslims saw and feared was that in the decades following the reconquest of Toledo, the indigenous Muslim population was rapidly losing its numbers, and as a result, its identity. The Christian frontier was slowly, but surely, creeping sothward. In the years after Toledo's recapture, the intersections between slavery and social identity would play a profound role for Christian and for Muslim, for the city of Toledo and for Spain, and for Spain's history and its future.

Gothic rule and Gothic Christianity were, for all intents and purposes, inseparable. And for Toledo, as Hannah Lynch writes, "Gothic rule ... is little else but the story and development of Gothic Christianitys ${ }^{15}$. The Toledan Church councils not only set out standards for liturgical rite and Christian convention, but they also worked out, in conjunction with the Visigothic secular institutions, a corpus of laws which would later play an important role in establishing autonomous Mozarabic rule, both during and after the Muslim domination of the city. This corpus of laws, codified in a text known as the Liber Judiciorum, although not entirely political, eventually became a politi$\mathrm{cal}$ handbook for the Mozarabs. When they had achieved self-rule, after the reconquest of Toledo, the Mozarabs employed the Liber Judiciorum as the basis of the law to be later adjudicated in their communities, by their own judges and courts. These laws would hold jurisdiction over many secular matters, including the enforcing of the terms of emancipation charters.

One of the earliest towns of Spain to embrace Christianity ${ }^{16}$, Toledo would eventually become the capital for the Visigothic kings. Politically speaking, this was of profound significance, for it centralized Visigothic rule under one person, ruling from one city. Quickly the city's name also became synonymous with Visigothic Christianity. After Muslim conquest of the city, it became a sanctuary of sorts, a hallowed city. Its legacy was of the utmost importance for Spanish Christians everywhere, from those of North Iberia to the Mozarabs in the Southern cities ${ }^{17}$.

15. LYNCH, p. 21.

16. LYNCH, p. 18.

17. GLiCK, Thomas, entry a Toledon in the Dictionary of the Middle Ages, vol. 12, p. 68. 
Toledo's period of Visigothic rule was not the only time it obtained a renowned name. Once under Muslim control, Toledo achieved its greatest physical extent, 43 acres, its highest population, 37,000 people, and achieved a reputation as a sophisticated center of learning, philosophy, and art ${ }^{18}$. As Gabriel Jackson comments, "the ancient city of Toledo, now the home of an important school of translators, and with its traditionally sizable Mozarab, Jewish and Muslim quarters, lived a far more cosmopolitan, artistic and intellectual life than did the other towns of the mesetan ${ }^{19}$. Arabic accounts of astronomy, medicine, philosophy, and mathematics, although originally filtered into Western Europe by the Crusaders' return to their homelands, now had a nearer proximity to Western Europe, through the Cluniac translators of Toledo. Under the patronage of the Cluniac archbishop Raymond (1124-1151), after the city's reconquest, Arabic texts were translated into Latin, rapidly spread across the whole of Spain, and eventually filtered into the rest of Europe.

For the Toledan Christian nobles and their loyal subjects, the advancement of Tarik was a most unwelcome event. In the span of roughly a week, their entire world, their way of life as they had known it for centuries, disappeared. However, for a small group of individuals, the Christian way of life would, and did, persevere. For the Mozarabs of Toledo and other Muslim-held cities, their common religion, which demonstrated a greater allegiance to Toledo and Santiago de Compostela than to Rome, bound them into a tightly-knit social class that clung fervently to its older ways. Although they did assimilate some of the ways of life of their liberal Muslim masters, the Mozarabs kept their particular brand of Christianity, their liturgical rite, and their identity whole.

Many Toledan Mozarabs had a choice to make: quietly to accept the Muslims as the new leaders of their city or to stand up to them. Opposition to Islamic domination could be expressed, Reilly notes, either peacefully, «as in the public denunciation of Islam ... [or] it might be marked by participation in active revolt in the countryside ${ }^{20}$. An example of such active revolt is the revolt of the Mozarabs of Córdoba (c. 850-859) ${ }^{21}$. The main cause of the revolt, according to Jackson, was sthe despair with which an educated minority of the Mozarabs witnessed the steady religious and cultural attrition of their community ${ }^{22}$. This fear of too much stagnation of culture caused these particular Mozarabs to invite public matyrdom by denouncing Islam and denigrating the name of Mohammed. Such actions, as mentioned earlier, were forbidden by Islamic law. Indeed, offenses such as publicly insulting Allah were punishable by death.

Mass emigration to the Christian kingdoms of Asturias and Castile was also an option for many a Mozarab. Some historians believe that the emigra-

18. GLICK, p. 68.

19. JACKSON, Gabriel. The Making of Medieval Spain, p. 96.

20. REILIY, p. 73.

21. JACKSON, p. 31.

22. JACKSON, p. 31. 
tion of thousands of Mozarabs to the north may even have planted the idea of reconquest firmly in the Christian kings' minds. Derek Lomax supports this thesis by noting that the Mozarabs may have wencouraged the rulers of Asturias to commit themselves more definitely to the programme of the Reconquest ... they certainly brought with them learning and almost as certainly, a greater feeling for Christian and Visigothic traditions $x^{23}$. For the Christians of northern Iberia, the Mozarabs represented a social force, a group of people who kept a vision alive and hearkened back to an older, glorious epoch in the history of Toledo and Spain.

Rebellion was always a part of Toledo's history, and of the Mozarabs' history, since the city's initial Muslim conquest. Although there was active revolt, such as the active agrarian revolt of ibn Hafsūn in the late ninth century ${ }^{24}$, there were also sympathetic Mozarabic revolts in Toledo for their other Mozarab bretheren in other cities. During the years of intermittent rebellion, Mérida, Toledo, and Zaragoza, in the inland regions of Spain, and the coastal areas of Málaga, Almería, and Murcia were the principal foci of discontent ${ }^{25}$. For the advancing Christian armies, Toledo was a prize worth fighting for, both because it had a large Mozarab population and because it had a long a tradition of revolt against the amirs and caliphs of Córdoba. Moreover, once it was recaptured by Alfonso VI, "Toledo was the greatest city that the Christians had ever captured, and its fall marked a change from the occupation of countryside and small towns to a seizure of the great centres of population, wealth and power ${ }^{26}$. For the Mozarabs in Toledo, who had actively and passively resisted Muslim hegemony, a new era was dawning. Now the Muslims were faced with a choice. Like the Mozarabs before them, aemigration [from al-Andalūs] seemed the only alternative to humiliation at Alfonso's hands $n^{27}$.

Tension between Muslim and Christian in Toledo - before, during, and after the reconquest of the city - had always been present. And the period of religious crusading only helped to exacerbate this tension between the religious groups. Muslim-ruled Toledo was a buffer for advancing Christian forces. Supporting this, Lomax writes athe frontier between Christian and Muslim territory seemed almost static for half a century and the successor-states of the caliphate settled down under their [Hispano-Arabic] rulers in ... Toledon ${ }^{28}$. Prior to the reconquest of Toledo in the later eleventh century the call to arms was heard across Europe. In 1075, Pope Gregory VII announced "the project of an armed expedition against the enemies of God", which he stated in one of his letters was "designed to go to the Lord's Sepulchre" $n^{29}$. The vigor of this

23. Lomax, Derek W. The Reconquest of Spain, p. 30.

24. REILLY, p. 73.

25. JACKSON, p. 31.

26. LOMAX, p. 66.

27. Lomax, p. 67.

28. LOMAX, p. 51 .

29. Carleton Munro, Dana. *The Western Attitude Toward Islam During the Period of the Crusades", Speculum, vol. 6. p. 330. 
atmosphere of Crusade was, for Iberia, merely an extension of the military conflict between the Christian kings and Muslim caliphs. For the rest of Europe, the conflict was seen as battling the same enemy, only now closer to the European countryside. One did not have to travel all the way to Jerusalem to find salvation and glory; one could cross the Pyrenees and join the conflict in Spain.

With the Crusades came the propaganda of crusading: «the Muslims were held up to detestation or worshippers of false and idols ... The History of Charles the Great and Orlando by the pseudo-Turpin, recounts how "the Emperor utterly destroyed the idols and images in Spain, except in Andalusia" ${ }^{30}$. Such propaganda did not cease with either the reconquest of Spanish Muslim cities or the capture of Jerusalem by the Christians. Peter the Venerable, in a visit to Spain around 1141, remarked that she could not decide whether the Mohammedans were pagans or heretics, but in either case their teaching ought to be refuted and ridiculed ${ }^{31}$. Muslims were not only the targets of such propaganda, but also used similar tactics against Christians. In the propaganda wars, the central tenet focused upon was monotheism. Both Islam and Christianity held monotheism as paramount, as the true religion. And each religion fingered the other for committing the sin of practicing polytheism. Helen Adolf comments, "Christians blamed Islam for worshipping Apollo, Mahomet [sic], Tervagent, and half a dozen other idols ... Moslems accused Christians of having three gods: Allah, Maryan (Mary), and '̄'sà (Jesus) $n^{32}$. The propaganda on both sides stirred thousands of warriors, Christians and Muslims, to fight for their respective religions, in all venues of Europe and the Middle East, from Spain to Sicily, from Damascus to Jerusalem, and from Acre to Antioch.

The casualties of these wars of religion were not always those who died. There were also thousands, Muslims and Christians alike, who survived these wars to live as slaves. J.N. Hillgarth remarks, wthe main source of supply of slaves for all the Christian kingdoms was war. Slaves were normally Muslims, captured during military campaigns $n^{33}$. However, both Christians and Muslims were enslaved during these wars. According to Saco, "the Christian enslaved the Muslim and the Muslim the Christian; even if it is necessary to confess that the tendency to enslave was more developed in the disciples of Christ than in those of Mohammed $n^{34}$.

Slavery, in Spain and in the history of Europe, was nothing new. Millions of people in the course of history had been enslaved since antiquity, whether by physical loss of freedom due to war, encapture by raiding slavers, or other

30. MUNRO, p. 331.

31. MUNRO, p. 337.

32. ADOLF, Helen. *Christendom and Islam in the Middle Ages: New Light on "Grail Stone" and "Hidden Host" n, in Speculum, vol. 32, p. 105.

33. Hiligharth, J.N. The Spanish Kingdoms 1250-1516, p. 86.

34. SACO, José Antonio. Historia de la esclavitud, p. 124. 
means. However slavery in Spain, and the slave trade there, developed somewhat differently from other parts of Europe. For one thing, Christian, Jew, and Muslim all played very important parts in the history and development of slavery in Spain.

The role of slavery in history and, in particular, in medieval Spanish culture, must first be outlined before any discussion of particularities in the Toledan region can be attempted. The practice of slavery, according to Orlando Patterson, has occurred in almost every society. Patterson writes that slavery "has existed from before the dawn of human history right down to the twentieth century, in the most primitive of human societies, and in the most civilized ${ }^{35}$. However, that does not justify the practice of slavery. The presence and perpetuation of slavery, although a constant of human history, does not excuse its barbarity.

Slavery, as defined by Pierre Dockès, is "not one type of domination and exploitation among others, not merely an aspect of one bygone phase of history. Slavery is the primary and primordial relation of exploitation out of which serfdom and wage labor arise and that form toward which the master always strives: only force can compel the master to forgo the use of slaves $w^{36}$. Slavery was vital for the survival of the Roman world, for example. Slaves carried on dayto-day business for their masters. They ran errands, delivered messages, bought food and goods for the house ${ }^{37}$. The slave was an essential part of the management of the Roman home, a sign of both its prosperity and its stability.

What was the slave essentially? What is slavery and what is the identity of the slave? To the question of "What is slavery?" Roman law defined the slave according to three categories: how much use or enjoyment one could garner from his or her slave, how much profit or return that slave produced, and what penalties and/or fines were exacted upon those who abused their own or others' slaves. Slavery, both in antiquity and in general, occurs as the result of a consequence. Dockès defines the slave as "one who should have been killed [in combat] and who survives by the grace of the master; he is one of the "living dead" (mort-vivant) ${ }^{38}$. Not only is he considered to be a "living dead man" because he had been physically reprieved from a death sentence, but also because he has been physically removed from his homeland, his patria. "Perhaps primarily ... his ties to his native soil, his family, and his community had been broken ${ }^{39}$. Faced with the loss of identity, for many a slave the only option, besides death or manumission, was to assimilate himself or herself to the society of his or her master.

Slavery in Roman Spain developed the same characteristics and legal measures as it did in other Roman-governed areas. Even after the withdrawal of

35. Patterson, Orlando. Slavery and Social Death: A Comparative Study, p, vII.

36. DOCKES, Pierre. Medieval Slavery and Liberation, p. 2.

37. BLOCH, Marc. Slavery and Serfarm in the Middle Ages, p. 1.

38. DOCKÈs, p. 4.

39. DOCKEs, p. 7. 
Roman sovereignty from Spain, the institution of slavery continued unabated. Slaves were an integral part for the management of the countryside. Their importance did not diminish as the Roman presence diminished. The Roman system of colonial-type plantations worked by series of slaves continued, and would eventually form the basis of smaller, manorial plots of land worked by rent-paying workers. According to Bloch, wtoward the end of the Empire, this system was generally abandoned. The large landowners, taking advantage of their possession of large expanses, parceled them into little farms whose occupants paid rent in a variety of forms ${ }^{40}$. These smaller farms, the ground work for a later, although weaker, feudal-type system of land ownership, owed their roots in the large, slave-worked farms of Roman Hispania.

The Visigothic rulers of Spain also had uses for the existing slave system. But there remained a fundamental difference between the Roman and Visigothic legal codes for slaves. The identity and existence of the Roman servus was acknowledged and codified by legal codes. The Roman slave, more often than not, took the identity and name of his or her master, for example, becoming an inseparable part of the latter's household. The slave in Visigothic Spain, however, was barely considered to be human. He was relegated to a status somewhere between animal and human, recalling the Aristotelian classification of the slave as «an animate instrument, like an animal, but more efficient than an animal, being endowed with speech ${ }^{41}$. The Visigothic slave was not a legally acknowledged part of his master's household, for example. Rather, he or she merely became an extra set of hands to work the fields. This slave had no social or legal identity at all. aAny person reduced ... to the rank of slave lost his identity and found himself de-socialized .... One of the essential features of Visigothic legislation was to relegate the slave to a sub-human condition. The term used for him - mancipium - was neuter in gender, as if it applied to an object. The slave was, in effect, a thing. Or more exactly, an animal $_{n}{ }^{42}$.

The early and medieval Church's justifications for slavery were contradictory. The slave was both divine and lowly, more than an animal, but less than human, a creature both sacred and profane. According to Bonnassie, the Christian justification of slavery was enshrouded in, and defined by, both Christian dogma and the reality of the economic world:

Christianity tended to detach slaves from the animality in which they were confined ... But ... the clergy legitimated slavery, and made it an institution of divine origin ... Another idea given wide currency was that slavery was synonymous with baseness. Slaves were collectively guilty and thus responsible for their lot; if, in effect, they were not intrinsically perverse, it was impossible to understand why God kept them in such a condition. And finally, on the concrete level, the Church

40. BLOCH, p. 5.

41. DOCKks, p. 7-8.

42. BONNASSIE, p. 72. 
was reluctant to enfranchise its own slaves ... and seems by no means always to have treated them gently $y^{43}$.

If justifications for slavery were complex and contradictory, manumission of the slave, in the eyes of the Church, was nevertheless a noble act. Although the Church may have been reluctant to free its own slaves, it did urge other Christians to manumit their slaves. Moreover, the Church defined manumission in purely religious terms:

since God has originally created all men equal and since, in addition, Christ had suffered for all men equally and at the price of his blood had manumitted them from the servitude of Original Sin, to bestow liberty was for the master not a stern duty but at least an infinitely commendable act whereby the faithful, raising himself so far as to imitate the perfece life of the Savior, worked for his own salvation ${ }^{44}$.

Thus, in the act of manumitting his slave, the master became quasi-divine. Through the act of manumission, the master had the potential to imitate Christ, and the slaves had the potential to inherit the earth.

Along with art, science, and philosophy, the Muslim invasion also brought its own style of slavery to Spain. Gordon points out that slavery was an institution with firm, historically developed roots in Islamic and Arabic history. In Muslim culture, Gordon continues, the slave "was both chattel and person ... his owner had full title to him, enjoyed the fruits of this economic surplus, and ... could sell or dispose of him (or her) as he saw fits ${ }^{45}$. The duties of the slave in the Islamic world were various. According to Gordon, the Islamic slave was "sought after in Muslim society to perform household chores and to serve in harems ... to fill in the ranks of ... [the] armies and to serve in the bureaucracyn ${ }^{46}$. The slave in Islamic societies had a more direct influence upon his society than his medieval, Western counterpart. In addition, the slave in Muslim society did not suffer the same alienation as did the slave in Christian Europe. The slave in the Arabic world could far more readily assimilate himself or herself into society. Gordon notes that islaves, because of the integrative nature of Islam, whose tenets made it easy for slaves to enter the fold, did not feel like strangers in Muslim society. Social stratification in this society was far less rigid than in the West ${ }^{47}$. The slave, although property, was nevertheless human, and the slave's responsibilities within the Muslim household provided him or her with many of the tools necessary for life as a free person in Islamic society, if and when manumission could be obtained.

Manumission and Islam were not mutually exclusive. Although in Islamic society some people were cast into their roles as eslaves for God" and "slaves

43. BONNASSIE, p. 74.

44. B1OCH, p. 14.

45. GORDON, Murray. Slavery in the Arab World, p. 14.

46. GORDON, p. 14.

47. GORDON, p. 15. 
for both God and his creaturesn ${ }^{48}$, freedom for those slaves was not an unattainable goal. Since Islam forbade the enslavement of any free Muslim or Christian or Jew, a slave in an Islamic society had to be, by definition, an outsider. But since the nature of Islam allowed slaves to incorporate themselves into Islamic society, the outsider could become an insider through his or her tenure as a slave. Indeed, as Shaun Marmon writes, "the ideology of Islamic slavery could best be described as one that articulated slavery as a social process -a means of converting outsiders into insiders ${ }^{49}$. The period of slavery in Islamic culture was thus, in some sense, a learning time, a time when the slave would acquire a new name, a new role, a new identity. The beginning of the end of enslavement, when the eliving-dead" person would be sresurrected", involved a period of training, the tarbiya, where the young slave "was socialized into Islam and into the household of the master ${ }^{50}$. This tarbiya varied from household to household and from slave to slave. However, one important common thread that ran through each separate tarbiya was that the slave, male and female alike, would receive a rudimentary education in Islam. Such an education would, in effect, prepare the slave for entry into Islamic society and to obtain his or her own identity in that society.

The end of this training period culminated, more often than not, in manumission in early adulthood. The conditions of enslavement and manumission relied upon very powerful metaphors, of death and resurrection, respectively. As Shaun Marmon notes, «the unbeliever who had "died" to his or her former life was now "reborn" as a member of the Muslim community, fully integrated into a social network, the core relationship of which was his bond of loyalty with his manumitter ${ }^{51}$. This bond did much to imprint a sense of belonging on the slave's mind. Bound to his former master, the newly-freed "reborn" individual became part of a world that formally acknowledged him as a valuable asset, one who was regarded as essential to the well-being and maintenance of Islamic society.

Thus manumission took on different meanings in the Christian and Muslim worlds. For the Christian, to emancipate a slave was an act of piety, a chance to emulate the principles of his or her religion. For the Muslim, freeing a slave was not only an act of nobility, but a lengthy process incorporating the individual into a collective identity and society. Manumission, although a potential reward for a slave, set in motion a new relationship between master and servant. The very act of bestowing liberty was often characterized as being even greater than granting the captured soldier, whether he be Christian or Muslim, a reprieve from death. The master, by freeing his slave, was committing both a noble deed and deepening a bond. The freedman not only owed his

48. Marmon, Shaun. Entry *Slavery, Islamic World" in the Dictionary of the Middle Ages, vol. 11, p. 330.

49. Marmon, p. 332.

50. MARMON, p. 332

51. MARMON, p. 332. 
master his previous life, but also his newly achieved freedom. Whatever deeds the freedman committed henceforth were understood to be, in some way, a continuing reflection of his former master's reputation and status. Therefore, in some senses, in granting freedom, the master bound the former slave even tighter to his person. Freedom was not a gift given lightly. The master or group that previously owned the slave did not want to jeopardize their name, especially if the former slave proved to be rambunctious. Thus many charters of emancipation required that elaborate conditions - moral, financial, or laborcontingent - be fulfilled prior to total and complete freedom. Moreover, many of those same charters established a penalty for failure to complete the required conditions. Such penalties not only included higher fines or a longer period of tenured labor, but they more often than not also stipulated a return to a servile status.

In post-reconquered Toledo, the Mozarab population was clearly in the dominant position. However, they were not the only segment of the population of the city. The population of Toledo also included Muslims, Jews, Castilian settlers, and even French colonists ${ }^{52}$. After the conquest of the city by Alfonso, the Mozarabs had been given rights and repayments denied them under Moorish rule, including the right of nearly autonomous self-rule ${ }^{53}$. The Mozarabs had jurisdiction in their own courts and practices. Moreover, the Muslim population had been dwindling steadily since the reconquest of Toledo, due to conversion, flight, captivity, or downright slaughter. Also, after 1085, the Christian kings, when conquering Muslim-held towns, «moved Christian settlers into the new lands and often, though not always, expelled the Muslims ${ }^{54}$, in order to cement the loyalties of their towns. Thus, the Muslims were faced with an alarming situation. As their own populace rapidly lost dominance and became assimilated into Christian culture, the Muslims felt a certain degree of apprehension.

In investigating the eleven manumission documents from Toledo, dated between 1201 and 1320, one must keep in mind that these are Mozarab accounts. The documents were established by Mozarabs, operaring on their own set of laws, and within their own jurisdiction. Mozarabs drew them up, set the terms and limits for emancipation, imposed the penalties for failure to follow the word of the letter, and witnessed and signed the documents. As a set of legal briefs, the documents stipulate, at times in very complex terms, what was needed to be completed by the Muslim slave in order to achieve his or her freedom. Although the documents do not show as much emotional content as a personal journal would, they did change as time passed. Originally gifts, the documents became legal briefs at the end of the period studied. This reflects two things: the growing importance of sstandardizing" emancipation documents, and more importantly, the change in the relationship between 
Mozarab master and Muslim servant. Although written in Arabic, the documents outlined the requisites according to Christian conventions. The terms were not exclusively Christian, for both Islam and Christianity shared many conventions of culture. Yet, as seen in the wording of the documents themselves, and in the witnesses of the documents, it cannot be denied that Christian influences were heavily felt.

The Mozarab manumission documents were written and delivered in a contractual style. Marc Bloch, in his investigation of emancipation documents from the late Roman Empire through the medieval era, notes that there are generally two different categories of charters: «the collection of formulae distinguish them under the expressive names of manumission with or without obedience, manumissio cum or sine obsequio, the only distinction which was really important from the point of view of the social structures ${ }^{55}$. The Muslim point of view, in seeing their own people being emancipated with many exorbitant repayments and requirements, was one of distress. Although emancipation did free up and add more members to Islamic society, it was done only with the strictest of guidelines, as imposed by the Christian emancipators. The slave could not be fully emancipated and brought into Islamic society as a contributing member without a prior period of training, at least as it was generally accepted in the Islamic mentality. The free Muslims undoubtedly imposed an implicit pressure upon the Mozarabs to free their slaves. However, the Christians decided to emancipate their slaves exclusively on terms that they themselves established, as demonstrated in the emancipation documents. This served a two-fold purpose: it allowed for more people of Muslim descent to enter Islamic society and thus ease Muslim pressures for emancipation (uniess they were forced to convert as instructed by their letters of emancipation) and it allowed their potential freedmen to act as a source of indentured labor for an extended period of time, binding them even tighter to the yoke of the master.

The obsequia, or the various acts of obediences and duties the slave had to perform in order to achieve freedom, was nebulous. Bloch remarks that it unot only consisted of a general duty of subjection, with more or less vague outlines and promise of support in return, ordinarily it comprised very precise obligations, at times specified by the act of manumission itself, at others prescribed by a group of customs known to all ${ }^{56}$. The terms of manumission and the obsequium, moreover, were not always the domain of just one person. Sometimes groups of people or institutions established their guidelines. At times, according to Bloch, the master agave his rights to a third party that, more often than not, was a church. Already an act of piety in itself, a manumission became, in this case, doubly so, since it accompanied a donation to the servants of God $x^{57}$. The services of the emancipated slave could, and often times did, belong to the domain of the Church instead of solely one master. 
Both Larry Simon and Shaun Marmon agree that there is very little quantitative data and documentation dealing with population numbers and personal accounts from this period. For this thesis, eleven documents concerning emancipation, which appear in Ángel González Palencia's Los Mozárabes de Toledo en los siglos XII y XIII, have been translated and analyzed. Of the eleven Toledan documents studied, six were delivered implicitly as manumissio cum obsequio, through their terms of emancipation. One document, dated October 1289 , even returns a freedman, a certain Garcia, to slavery for failure to complete the terms of emancipation as laid out in his charter. The majority of the documents share one common thread. Whether they are testimonial or granted during the master's lifetime, whether it is one person or a group of people who grant freedom, the slave receives his or her identity from some other individual or group and is not allowed to establish it for himself or herself. He or she can not forge it, as in the tarbiya, nor can he or she really become part of the master's household. True, earlier in the time period studied, the documents are worded almost as gifts, but the documents later become mere legal briefs. The slaves' former masters worked out terms of legal and social identity for them, as opposed to the slave establishing such social parameters for himself or herself.

People other than the individuals named in the documents were also affected by charters. For example, the terms of emancipation sometimes implicated fellow slaves or familly members of the person seeking emancipation. Document 787 , after outlining a program of redemption payment and labor for Ali ben Abderrahmen el Basti, then goes on to stipulate that his wife and son are to stand bonded. Their inclusion in the terms of the document ensures, or attempts to ensure, Ali's fulfillment of the terms regulating his emancipation. If he does not, or more accurately, if he flees, his family will bear the brunt of his punishment. Such practices by masters in emancipating their slaves were not uncommon. Document 790 shows this practice as well. Not only does this document set out terms of labor for three Muslim slaves, but the jobs establish, in explicit detail, a moral code the men have to follow. In one document, there is a stipulation that eif they flee, even if it is one or all of them .... they will lose what they have worked for and they will return to slavery ${ }^{58}$. In another, if a slave were to escape and does not reappear ${ }^{59}$, the others would have to make up his work in the vineyards of the convent of San Clemente. Many of the people who are emancipated thus share their rewards and punishments with friends and family. Emancipation effectively established a new web of social relations for the emancipee.

Muslim identity was not the only issue under scrutiny. Women's rights and responsibilities are delineated in these documents as well. Five of the twelve emancipated people are women. In the medieval Islamic world, the female 
slave sprocuded free, legitimate offspring for her master, [and] her childbearing potential was a crucial determinant of her market value and of her future roles ${ }^{60}$. For the female Muslim slave in Mozarabic culture, however, events and circumstances were slightly different. It was probably not of foremost concern in the Mozarab master's mind that female Muslim slaves breed other generations of slaves. Rather the female Muslim slave, for the most part, was expected to perform domestic duties for her master(s). In the women's cases, no precise work duties were established. Unlike their male counterparts, the women, in setting out the terms of their redemption, were not forced to work in the agricultural sector of Toledo. Redemption payments were established, of course, but the means of obtaining that money was couched in vague terms, only "to work in Toledo and in its suburbw ${ }^{61}$. The women's charters were not very specific in outlining the labor-related terms of their emancipation. Yet the charters were very explicit in establishing moral guidelines for the women. Like the men, the women were prohibited from mixing with bad company, fleeing, and failure to pay their redemption fee. Yet women were faced with an additional restriction: they could not raise their money through prostitution. Failure to follow these moral mandates would return the woman to her previous status as a slave.

Perhaps one of the most interesting accounts of those under consideration here is document 793, dated December 1293. A woman, Omalhada, described as the kdaughter of Hasan el Ansari ${ }^{62}$, is married to a Muslim, Yaix el Sastre. Their marriage, priced at $281 / 2$ Alfonsi mizcales, in effect emancipates Omalhada, provided that both Yaix and Omalhada work in Toledo to pay their fee. Their starting date of payment, and the payment plan itself, is set out in very complicated legal language and the document established moral guidelines for the two. The sins of Omalhada, it states, fall upon Yaix as well as herself. Moreover, if Yaix drinks wine or commits the sin of usury, in addition to the normal penalties incurred in the event of failure to pay and/or flight from Toledo, Omalhada would return to slavery. Yaix, for his part, could be imprisoned without judicial proceedings at the behest of Omalhada's emancipator, Doña Colomba. Also, the couple has an obligation to pay the woman's social dues by providing her with a gift eat each of her three parties, without excuse or pretexo ${ }^{63}$.

This document is fascinating both because of what it reveals and what it hides. The document is dated from the end of the period studied, late in the thirteenth century, Compared with document 785, this charter is remote and distant, written in the strictest of legal jargon. Absent is the hope of the earlier document, of Don Roman ben Selma's care for his converted slave, Maria Julianes. Described in a lofty, almost elegant style, her emancipation is described

60. MARMON, p. 333.

61. Palencia, p. 59

62. PALENCLA, p. 64.

63. PAlenCIA, p. 65. 
as being "brought from slavery by baptism... placed among the Christian free people... by the love of God $\eta^{64}$, and Maria is presented the charter as a tangible object of her master's hope for her future. Yaix's and Omalhada's charter shows the regulation and standardization of emancipation, the further detachment of the Mozarabs from the Muslims. Though they «will be [made] free, equal to the rest of the Muslims» ${ }^{65}$, the couple is remote from their mistress. The documents for emancipation become, by the end of the time period studied, legal briefs, not gifts.

The practice of slavery in Spain continued until the beginning of the nineteenth century, long after the period under consideration in this thesis. Spanish ports continued to be slaving centers for a growing empire. William Phillips writes that eslavery subsisted in the Peninsula with more vigor than in any other part of Christian Europe, except Italy ${ }^{66}$. The practices of Muslims enslaving Christians and Christians enslaving Muslims were not without repercussions. After the complete expulsion of both Muslims and Jews from Spain in 1492, Spain's policy of enslavement and Christian dominance was brought to its neighbors and across the Atlantic. J.H. Elliott remarks, whe experiences of the "Reconquista had led to the formulation of an elaborate code of rules about the "just war", and the rights of the victors over the vanquished population, including the right to enslave it. These rules were extended ... to the Canary Islands ${ }^{67}$. The discovery of the Indies, while it filled Spain's coffers with thousands of pounds of silver and gold, also resulted in the enslavement of thousands of men, women, and children. This in turn led to the establishment of the encomienda system, described by Elliott as ubarely distinguishable from outright slaveryn ${ }^{68}$. Eventually, both slavery and labor services provided by the encomienda would be the driving forces behind the economic exploitation of the New World. Spain's legacy of slavery would have an impact upon thousands of people, and thousands of miles away from the Iberian peninsula.

The early stages of the development of Toledo is defined, in part, by the geography of Spain. The harsh geography of Iberia forced people into very tight-knit communities, fiercely devoted to their separate ways of life. Toledo, one of those enclaves, was an ancient city, heir to a proud, revered legacy of Christianity. That peculiar blend of Christianity developed separately from Roman influence. However, Toledo was also heir to a tradition of Islam after the Muslim conquest of the peninsula in the eighth century. This dual-identity of Toledo, as both a Christian and Islamic bastion, was the product of a populace that was exposed to both religions' influence. Muslims, Jews, and Mozarabs were vital to the lifeblood of the city. The city's identity was shaped by the influence and interaction between the various cultures.

64. PALENCIA, p. 57.

65. Palencia, p. 65.

66. PhIцıPs, William D. Jr. Historia de la Esclavinud en España, p. 106.

67. Eu.ıот, J.H. Imperial Spain 1469-1716, p. 69.

68. Eџиот, р. 70. 
Tension among the religious groups was a given. Crusader propaganda helped to exacerbate those tensions among the various ethnic groups. And after the Christian reconquest of Toledo, those problems intensified. Robert Burns writes, "the majority of Muslim population who remained [did not convert] experienced the social pressures inherent in their subordination and tended to acculturate in many small ways while simultaneously recoiling and hardening in their religious beliefs and social practices ${ }^{69}$. Between Muslim and Mozarab there was a fair degree of mistrust of the other. In addition, Christian setters moved in and monopolized reconquered areas. The rights the Christians were bestowed by the Christian Spanish kings, and the sweeping measures with which they used those rights, did not exactly ease tensions between the Muslims and the Christians.

The Mozarabs found themselves in a predicament. On the one hand, they received pressures from the Christian settler populace. The Mozarabs, although heirs to the legacy of Visigothic Toledo, were looked upon by other Catholics with no small degree of disfavor. They were viewed almost as dissenters, a group of people who distanced themselves from the utrues Catholic tradition. Reyna Pastor de Togneri notes that a "segregationist" policy existed on the part of the other Christians toward the Mozarabs. This atmosphere of uneasiness between Catholics who saw themselves allied to Rome, and by definition, the Christian kings who were allied with the papacy, and the Mozarabs, seen as suspiciously "Arabized", was prevalent.

Yet it is not the problems of Mozarab assimilation that have been addressed in this thesis. It is the examination of the tension between the Mozarabs and the Muslims during the period after the reconquest of Toledo. The remnants of a culture that had once dominated almost all of Iberia by the mid-eleventh century, the Muslims found themselves to be a dying breed by the beginning of the fourteenth century. A systematic cultural attrition was observed by the Muslims, as their numbers dwindled across the whole of Spain. From Majorca to al-Andalūs, and from all other subsequently reconquered areas of Spain, the numbers of free Muslims in the cities and countryside diminished. The Mozarabs, once under the dominion of the Muslim caliphs, found themselves to be the new masters of the cities. Their courts and laws held sway, and as such, they were the authorities who outlined the stipulations and terms of emanciparion for their Muslims slaves.

In drawing up these charters of emancipation, however, the Mozarabs failed to take into account Muslim conventions and practices. By forcing conversion, extensive periods of indentured servitude, and exorbitant fees on the Muslims seeking emancipation, the Mozarabs, in effect, distanced themselves from them. Though this is not explicitly described in the documents, over the period of time studied, the documents do change. From Don Roman

69. BurNS, Robert I., S.J. Entry *Spain, Christian-Muslim Relationsn in the Dictionary of the Middle Ages, vol. 11, p. 376. 
ben Selma's gift for Maria Julianes, at the beginning of the thirteenth century, the documents end up being "contractualized" by the end of the century, as in the charter for the three slaves, Mohammed Almenari, Omar Becero, and Ali el Romanquero el Gomari, of document 790. Maria Julianes' charter of emancipation was a tangible gift, presented to her in order uso that she can demonstrate it to whomever wishes to return her to slavery or servitudes ${ }^{70}$. The other slaves' charter was not as unique as Maria's. Not only is the document riddled with legal jargon and standard phrases, the document is also adated and duplicated ${ }^{\prime}$. This essentially shows the development of the charters into standardized legal accounts, and the growing importance of such regulation in the development of legal practices. Moreover, the charter, as they change in language and style, hint at the growing distance between the Mozarab and the Moor. The fees and work required for freedom increase as time passes. Also, the moral obligations the slaves had to observe grew more specific, as well as the severity of punishment for failing to observe these moral mandates. Although it is very hard to infer what exactly the Muslim population feared and felt, it can be reasonably assumed that tensions did not ease between the Mozarabs and the Muslims. The emancipation of the Muslim slaves, as drawn up by the Mozarabs, did not allow for a period of training in which the slave could construct his or her own identity and thus ease the transition from slavery to freedom. More often than not, the Muslim slave, after paying a steep fee and working for years at a time under a form of indentured servitude, was thrust out into the world. There was no tarbiya for the slave to go through, to acclimate himself or herself and achieve a sense of identity before entering Islamic society. The identity, both legal and social, that the slave received was constructed by his or her Mozarab master. And that identity was not sufficient enough to keep Islamic culture and identity stable on the Iberian peninsula, especially after the reconquest of Iberia's cities. At the end of the fifteenth century, the Reconquista effectively eliminated Muslim presence in Iberia. After seven hundred years of dominance, Islam would, by and large, be removed from Spain. And the cultural attrition that many Muslims feared would come to pass, the fear that their way of life would be irrevocably lost, occurred.

\section{References}

ADOLF, Helen, "Christendom and Islam in the Middle Ages: New Light on "Grail Stone" and "Hidden Host" ". Speculum, vol. 32, no. 1, January, 1957, p. 103-115.

BLOCH, Marc. "How and Why Ancient Slavery Came to an Endo. In Slavery and Serfdom In the Middle Ages. Trans. William R. Beer. Berkeley: University of California Press, 1975, p. 1-31.

Bonnassie, Pierre. From Slavery to Feudalism in South-Western Europe. Trans. Jean Birell. Cambridge: Cambridge UP, 1991. 
BurNs, Robert I., S.J. eSpain, Christian-Muslim Relationsw. In Dictionary of the Middle Ages. Ed. J.R. Strager. 13 vols. New York: Scribners', 1989.

DEsCOLA, Jean. A History of Spain. Trans. Elaine P. Halperin. New York: Alfred A. Knop, 1963.

DOCKES, Pierre. Medieval Slavery and Liberation. Trans. Arthur Goldhamer. Chicago: University of Chicago Press, 1982.

EuroT, J.H. Imperial Spain 1469-1716. London: Penguin Books, 1990.

GLick, Thomas. "Toledon. In Dictionary of the Middle Ages, Ed. J.R. Strager. 13 vols. New York: Scribners', 1989.

GONZAIFZ-PALENCIA, Ángel. Los Mozdrabes de Toledo en los siglos XII y XII. 4 vols. Madrid: Instituto de Valencia de Don Juan, 1926-1930.

GORDON, Murray. Slavery in the Arab World. New York: New Amsterdam Books, 1989.

Hillgarth, J.N. The Spanish Kingdoms 1250-1516. Oxford: Clarendon Press, 1976.

JACKSON, Gabriel. The Making of Medieval Spain. London: Thames and Hudson, 1972.

Lomax, Derek W. The Reconquest of Spain. London: Longman, 1978.

LYNCH, Hannah. Toledo: The Story of an Old Spanish Capital. London: J.M. Dent, 1898.

MARMON, Shaun. "Slavery, Islamic Worlds. In Dictionary of the Middle Ages. Ed. J.R. Strager. 13 vols. New York: Scribners', 1989.

MUNRO, Dana Carleton. "The Western Attitude Toward Islam During the Period of the Crusadess. Speculum, vol. 6, 1931, p. 329-343.

Patterson, Orlando. Slavery and Social Death: A Comparative Study. Cambridge: Harvard UP, 1982.

PHILups, William D. Jr. Historia de la Esclavitud en España. Trans. Leopoldo Fornés Bonavia. Madrid: Playor, 1990.

ReILIY, Bernard F. The Medieval Spains. Cambridge: Cambridge UP, 1993.

SACO, José Antonio. Historia de la Esclavitud. Madrid: Bibliotea Jucar, 1974.

SiMONET, Francisco Javier. Histaria de Los Mozárabes de España. 4 vols. Madrid: Ediciones Turner, 1867. 